\title{
Safe Method of Collecting Leukaemia Cells from Patients with Acute Leukaemia for Use as Immunotherapy
}

\author{
R. L. POWLES, T. A. LISTER, R. T. D. OLIVER, J. RUSSELL, C. SMITH, \\ H. E. M. KAY, T. J. MCELWAIN, G. HAMILTON FAIRLEY
}

British Medical fournal, 1974, 4, 375-379

\begin{abstract}
Summary
Leukaemia cells were collected from the blood of 72 untreated patients using a continuous-flow blood cell separator. The yield of cells was proportional to the number circulating in the patient, and up to $1 \times 10^{12}$ could be obtained in three hours. Complications of the procedure were mild, consisting of chills and shivering in $18 \%$ of patients. Leucopheresis at the time of diagnosis is an essential part of setting up a specific immunotherapy programme for patients with acute myelogenous leukaemia, and the lack of harmful side effects makes the collection of these cells ethically justified. The need for a centralized service to provide cells for this form of therapy is emphasized.
\end{abstract}

\section{Introduction}

Animal experiments have shown the importance of using tumour cells for immunotherapy of tumour-bearing animals (Haddow and Alexander, 1964; Mathé et al., 1969) and this effect can be additive (Parr, 1972) to the weaker benefit obtained by non-specific immune stimulants such as bacillus Calmett-Guérin (Halpern et al., 1959). A prerequisite of success, however, is to immunize with large quantities of cells (Parr, 1972). Treating cancer in man with immunological procedures has been tried for the last 80 years (reviewed by Currie, 1972), but definite evidence for success based on controlled trials has only been reported for acute leukaemia (Mathé, 1969; Powles et al., 1973 a). In other controlled studies the inability to establish therapeutic benefit after immunological treatment may be because either no cells (Medical Research Council, 1971; Children's Cancer Study Group, 1973) or too few cells (Bloom et al., 1973) have been used. Studies in patients with acute leukaemia (Powles et al., 1971 a) showed that more than $5 \times 10^{8}$ immunizing cells were required to change the in vitro reactivity of patient's remission lymphocytes against stored autologous leukaemia cells, this reaction probably representing host recognition of the specific leukaemia antigen(s). This response was transient unless the injections were given often. These findings suggest that to be therapeutic immunotherapeutic procedures in man must include frequent injections of between $5 \times 10^{3}$ and $1 \times 10^{9}$ irradiated leukaemia cells and this would de-

\footnotetext{
Institute of Cancer Research and Royal Marsden Hospital, Sutton, Surrey

R. L. POWLES, B.SC., M.R.C.P., Senior Lecturer and Honorary Consultant Physician

J. A. RUSSELL, M.R.C.P., Senior Registrar

C. SMITH, F.I.M.L.T., Research Technician

H. E. M. KAY, M.D., F.R.C.PATH., Consultant Haematologist

T. J. MCELWAIN, M.B., M.R.C.P., Consultant Physician

Imperial Cancer Research Fund, Department of Medical Oncology St. Bartholomew's Hospital, London E.C.1

T. A. LISTER, M.B., M.R.C.P., Research Fellow

R. T. D. OLIVER, M.B., M.R.C.P., Research Fellow

G. HAMILTON FAIRLEY, D.M., F.R.C.P., Professor
}

mand in toto at least $1 \times 10^{1 i}$ cells for each patient to be treated. Clearly, to obtain sufficient cells for treating leukaemia constitutes a major obstacle without the availability of a continuous-flow blood cell separator (Graw et al., 1969). We have previously shown that small numbers of leukaemia cells may be collected using such an instrument (Powles et al., 1971 a) and stored in a viable condition (Powles et al., 1973 b). We describe here how to collect sufficient leukaemia cells for setting up a clinical immunotherapy programme (Powles, 1973; Powles et al., 1973 a), and show how in many instances direct clinical benefit accrues to the donor by removing leukaemia cells in this way.

\section{Continuous Flow Blood Cell Separators}

Continuous-flew blood cell separators (Aminco Centrifuge, Travencol Laboratories Inc., Silver Springs, Maryland, U.S.A., I.B.M. 2990, Model 6 Experimental Blood Cell Separator, Endicott, N.Y., U.S.A.) are instruments which remove large quantities of white cells (Graw et al., 1969) or plasma (Powles et al., 1971 b) from the blood of man. The first of these instruments, the N.C.I./I.B.M. Cell Separator, was designed by Freireich and Judson and tested in dogs in 1965 (Freireich et al., 1965) and subsequently found to be safe in man (Buckner et al., 1969; Mathé et al., 1971). The principle of this instrument involved continuous centrifugation of blood in a special bowl. The blood, drawn from a vein in the antecubital fossa, passes into the bowl where it separates into red cells and plasma with a buffy layer of leucocytes between them. These components are continuously removed from the bowl by separate peristaltic pumps, the buffy layer is collected, and the rest of the blood returned to a vein in the other arm. The volume of buffy coat which may be collected follows the same limitations applied to normal blood donors and should not usually exceed $500 \mathrm{ml}$. The gravitational force used for separation is low $(25 \mathrm{~g})$ so most of the platelets remain suspended in the plasma which is returned to the donor. No haemolysis of red cells occurs (Freireich et al., 1965). The centrifuge bowl is made of polycarbonate which requires steam sterilization before each session, but all plastic tubing used to conduct the blood to and from the patient is disposable (Avon Medical Ltd., Birmingham) and new sets are used on all occasions. The total extracorporeal volume of the blood in the machine is about $350 \mathrm{ml}$ and, apart from the volume of the buffy coat being collected, represents the only blood volume change in the donor. All but about $40 \mathrm{ml}$ of this $350 \mathrm{ml}$ is ultimately returned to the patient.

\section{Use of Separator with Leukaemia Patients}

\section{ANTICOAGULATION}

Heparin alone was used for coagulation because anticoagulant citrate dextrose solution (ACD) caused nausea and calcium problems. If the patient had normal coagulation factors then the initial intravenous dose was $2,000 \mathrm{IU} / \mathrm{m}^{2}$ heparin followed by $1,000 \mathrm{IU} / \mathrm{h} / \mathrm{m}^{2}$ into the blood passing into the centrifuge bowl. When patients lacked clotting factors the 
dose of heparin was reduced, and additional platelets were transfused if required.

\section{COLLECTING LEUKAEMIA CELLS}

The 350-ml dead space of the machine was primed with saline except for patients who were very anaemic, when fresh donor blood was substituted. Atropine was given to reduce vagal stimulation resulting from the intravenous cannulae, and anxious patients were sedated with diamonphine. All patients were continuously monitored electrocardiographically using an oscilloscope. A mechanically adjustable bed allowed positioning of the patients without disturbing the cannulae and this was important if constant blood flows were to be maintained. The clinical condition of the patient was constantly observed during the procedure with particular regard to pyrexia and haemorrhage.

Blood flow through the separator was regulated to about $40 \mathrm{ml} / \mathrm{min}$ and the white cell pump was then used at rates sufficient to remove all the buffy layer visible in the bowl (between $2 \mathrm{ml}$ and $10 \mathrm{ml} / \mathrm{min}$ ). If the buffy layer was allowed to accumulate in the bowl then clumping occurred with blockage of the exit ports. With patients who had low initial white cell counts there was inevitable contamination of the leucocyte suspension with red cells.

The buffy coat was removed from the centrifuge bowl by a dual channelled pump which could be used to transfuse fresh donor blood back into the patient. Under these circumstances anaemia could be corrected without altering the patient's total blood volume. The same method was used to exchange red cells for white cells in patients with high white cell counts and often two or three litres of buffy coat could be removed. The length of time during which leukaemia cells were collected varied according to the accessibility of cells and the patient's clinical condition, but patients were connected to the separator for up to five or six hours without discomfort. The cells were collected into $70 \mathrm{ml}$ of ACD in a plastic (Fenwal Ltd.) blood transfusion pack and the whole of the extracorporeal circuit was closed to the air. The handling, storage, and viability of the cells collected has been described previously (Powles et al., 1973 b). A sample of all buffy coats collected was cultured for bacterial contamination, and blood cultures from the donors were examined before and after leucopheresis.

\section{SELECTION OF PATIENTS AS DONORS}

Patients under the age of 10 or those who were extremely ill or bleeding were not generally put on the cell separator. Renal failure per se was not a contraindication, panticularly when due to xanthine nephropathy, as removal of large quantities of tumour cells reduced the metabolic burden to the kidneys. For this reason all patients with very high counts, even if not in renal failure, should be considered for leucopheresis, particularly white cell/red cell exchange, so reducing the frequent massive production of xanthines when chemotherapy begins.

All patients were aware of their diagnosis before leucopheresis and in all cases written informed consent was obtained.

\section{Results}

Between Ootober 1969 and January 1973 leukaemia cells were collected from the blood of 73 patients (one twice, 50 with acute myelogenous leukaemia, 22 with acute lymphoblastic leukaemia, and one with an atypical myeloproliferative disorder. In all cases the I.B.M. Cell Separator was used.
The clinical data are summarized in the table. Forty-three were males and 30 were females. The age distribution did not have the general pattern for these diseases; nearly half the patients were between 20 and 40 years old, probably reflecting the generally better physical condition of this age group. Six patients were children (under 15 years old), and one of these was only eight; 10 patients were over 60 years old, the oldest being 73. It is difficult to make a realistic estimate of the proportion of patients suitable for leucopheresis of all those referred to our hospitals because of the many other factors involved over and above their clinical condition-for example, referral distance from the hospital. During the period studied about $70 \%$ of all patients with acute myelogenous leukaemia admitted to the Royal Marsden Hospital, Surrey, where the separator is situated, were leucopheresed. At St. Bartholomew's Hospital before the installation of a separator 130 new myeloblastic leukaemia patients were admitted between October 1969 and January 1973, and during this period only 26 were leucopheresed since this necessitated moving the patients 20 miles. The haematological condition of the patients before leucopheresis is shown in figs. 1-3. It can be seen that $34 \%$

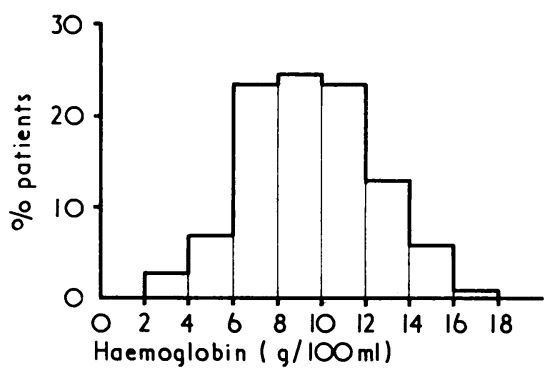

FIG. 1-Distribution of 73 patients leucopheresed according to initial blood haemoglobin concentration.

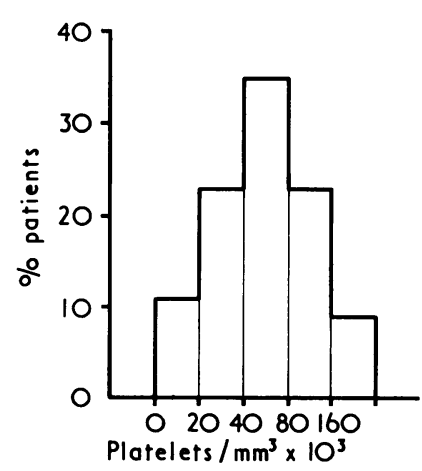

FIG. 2-Distribution of 73 patients leucopheresed according to platelet count.

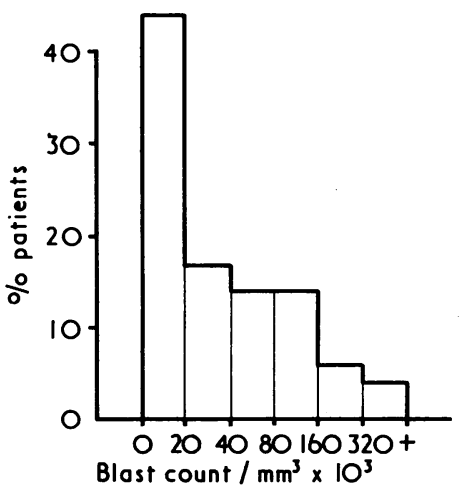

FIG. 3-Distribution of 73 patients leucopheresed according to circulating blast count. 
Clinical Details and Blood Counts before and after Removal of Leukaemia Cells in 73 Patients Investigated

\begin{tabular}{|c|c|c|c|c|c|c|c|c|c|c|}
\hline \multirow{2}{*}{$\begin{array}{l}\text { Case } \\
\text { No. }\end{array}$} & \multirow{2}{*}{$\begin{array}{c}\text { Age } \\
\text { (Years) }\end{array}$} & \multirow[b]{2}{*}{ Sex } & \multirow{2}{*}{$\begin{array}{l}\text { Presence of } \\
\text { Enlarged } \\
\text { Lymph } \\
\text { Nodes }\end{array}$} & \multirow{2}{*}{$\begin{array}{c}\text { Clinical } \\
\text { Condition }\end{array}$} & \multirow{2}{*}{$\begin{array}{l}\text { Presence of } \\
\text { Enlarged } \\
\text { Liver or } \\
\text { Spleen }\end{array}$} & \multirow{2}{*}{$\underset{(\mathrm{mm} / \mathrm{hr})}{\text { E.S.R. }}$} & \multicolumn{2}{|c|}{ Before Removal } & \multirow{2}{*}{$\underset{\left(10^{\circ}\right)}{\text { Yeild/hr }}$} & \multirow{2}{*}{$\begin{array}{l}\text { W.B.C. } \\
\text { After } \\
\text { Removal } \\
\left(10^{3} / \mathrm{mm}^{3}\right)\end{array}$} \\
\hline & & & & & & & $\begin{array}{l}\text { Platelets } \\
\left(10^{3} / \mathrm{mm}^{3}\right)\end{array}$ & $\begin{array}{l}\text { W.B.C. } \\
\left(10^{3} / \mathrm{mm}^{3}\right)\end{array}$ & & \\
\hline $\begin{array}{r}1 \\
2 \\
3 \\
4 \\
5 \\
6 \\
7 \\
8 \\
9 \\
10 \\
11 \\
12 \\
13 \\
14 \\
15 \\
16 \\
17 \\
18 \\
19 \\
20 \\
21 \\
22 \\
23 \\
24 \\
25 \\
26 \\
27 \\
28 \\
29 \\
30 \\
31 \\
32 \\
33 \\
34 \\
35 \\
36 \\
37 \\
38 \\
39 \\
40 \\
41 \\
42 \\
43 \\
44 \\
45 \\
46 \\
47 \\
48 \\
49 \\
50 \\
51 \\
52 \\
53 \\
54 \\
55 \\
56 \\
57 \\
58 \\
59 \\
60 \\
61 \\
62 \\
63 \\
64 \\
65 \\
66 \\
67 \\
68 \\
69 \\
70 \\
71 \\
72 \\
73\end{array}$ & $\begin{array}{l}48 \\
61 \\
45 \\
23 \\
53 \\
15 \\
58 \\
21 \\
20 \\
60 \\
49 \\
34 \\
34 \\
19 \\
16 \\
29 \\
30 \\
37 \\
37 \\
73 \\
61 \\
49 \\
61 \\
68 \\
23 \\
29 \\
27 \\
25 \\
24 \\
52 \\
19 \\
63 \\
28 \\
58 \\
46 \\
13 \\
22 \\
44 \\
71 \\
20 \\
54 \\
70 \\
59 \\
67 \\
47 \\
25 \\
57 \\
61 \\
33 \\
45 \\
23 \\
55 \\
51 \\
15 \\
8 \\
36 \\
10 \\
10 \\
13 \\
25 \\
18 \\
24 \\
22 \\
23 \\
19 \\
34 \\
26 \\
28 \\
14 \\
32 \\
60 \\
57 \\
26\end{array}$ & 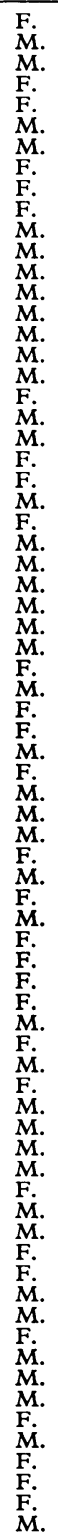 & 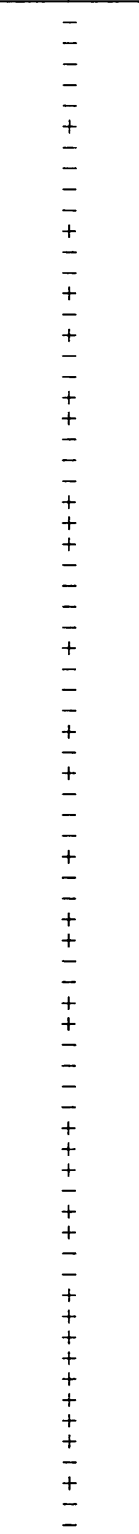 & 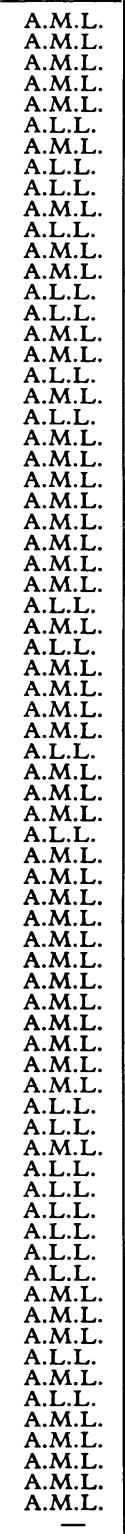 & 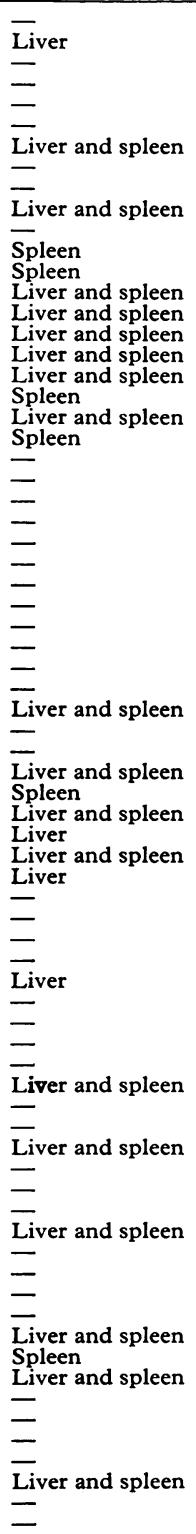 & $\begin{array}{r}65 \\
104 \\
108 \\
105 \\
73 \\
75 \\
9 \\
\\
\\
30 \\
35 \\
\\
83 \\
19 \\
\\
40 \\
120 \\
54 \\
98 \\
72 \\
100 \\
132 \\
100\end{array}$ & $\begin{array}{r}26 \\
36 \\
34 \\
142 \\
51 \\
65 \\
18 \\
8 \\
69 \\
295 \\
66 \\
8 \\
33 \\
40 \\
20 \\
114 \\
114 \\
105 \\
24 \\
96 \\
10 \\
240 \\
198 \\
38 \\
32 \\
40 \\
36 \\
98 \\
34 \\
60 \\
38 \\
60 \\
26 \\
158 \\
38 \\
44 \\
62 \\
214 \\
28 \\
36 \\
52 \\
46 \\
98 \\
60 \\
74 \\
38 \\
40 \\
92 \\
162 \\
42 \\
12 \\
102 \\
93 \\
30 \\
63 \\
12 \\
77 \\
142 \\
26 \\
47 \\
6 \\
120 \\
15 \\
142 \\
98 \\
122 \\
280 \\
38 \\
42 \\
36 \\
\end{array}$ & $\begin{array}{c}61 \cdot 5 \\
5 \cdot 8 \\
75 \\
36 \\
7 \cdot 6 \\
27 \cdot 8 \\
106 \\
34 \cdot 2 \\
5.6 \\
8 \cdot 0 \\
49 \\
8 \\
242 \\
457 \\
5 \cdot 0 \\
67 \\
9 \cdot 8 \\
685 \\
113 \\
8 \cdot 5 \\
11 \cdot 2 \\
9 \cdot 0 \\
41 \cdot 2 \\
46 \cdot 9 \\
108 \\
24 \cdot 9 \\
19 \cdot 8 \\
30 \cdot 9 \\
31 \cdot 4 \\
70 \cdot 8 \\
31 \cdot 3 \\
8 \cdot 1 \\
31 \\
107 \\
9 \cdot 5 \\
54 \cdot 4 \\
78 \cdot 7 \\
158 \\
7 \cdot 0 \\
265 \\
138 \\
54 \\
12 \cdot 1 \\
150 \\
71 \cdot 5 \\
31 \\
93 \cdot 3 \\
92 \\
36 \cdot 7 \\
90 \\
26 \cdot 9 \\
19 \cdot 9 \\
10 \cdot 2 \\
147 \\
111 \\
179 \\
12 \cdot 7 \\
14 \cdot 3 \\
6 \cdot 5 \\
23 \cdot 3 \\
95 \\
190 \\
186 \\
19 \cdot 5 \\
220 \\
43 \cdot 2 \\
18 \cdot 8 \\
48 \\
41 \cdot 6 \\
92 \cdot 9 \\
-9\end{array}$ & $\begin{array}{c}107 \\
7 \cdot 0 \\
100 \\
54 \\
1 \cdot 8 \\
25 \cdot 4 \\
13 \\
21 \cdot 1 \\
7 \cdot 3 \\
50 \cdot 5 \\
28 \\
59 \\
12 \\
198 \\
7 \cdot 6 \\
40 \cdot 4 \\
38 \\
550 \\
110 \\
54 \cdot 7 \\
14 \\
7 \cdot 4 \\
45 \\
84 \\
120 \\
35 \\
24 \\
53 \\
100 \\
13 \\
38 \\
25 \\
120 \\
120 \\
15 \\
75 \\
100 \\
60 \\
75 \\
11 \\
75 \\
36 \\
12 \\
210 \\
110 \\
62 \\
140 \\
100 \\
94 \\
120 \\
38 \\
20 \cdot 6 \\
24 \cdot 8 \\
70 \cdot 7 \\
192 \\
285 \\
38 \cdot 5 \\
24 \cdot 2 \\
13 \cdot 8 \\
57 \\
190 \\
290 \\
190 \\
590 \\
100 \\
42 \\
120 \\
200 \\
720 \\
230 \\
-\end{array}$ & $\begin{array}{c}44 \cdot 5 \\
3 \cdot 3 \\
36 \\
19 \\
3 \cdot 1 \\
22 \\
83 \\
34 \cdot 4 \\
4 \cdot 2 \\
4 \cdot 4 \\
31 \cdot 1 \\
13 \\
146 \\
324 \\
6 \cdot 3 \\
50 \\
530 \\
93 \\
93 \cdot 4 \\
15 \cdot 4 \\
8 \cdot 4 \\
8 \cdot 4 \\
22 \cdot 5 \\
29 \cdot 4 \\
65 \cdot 3 \\
20 \cdot 0 \\
18 \cdot 8 \\
28 \cdot 3 \\
23 \cdot 1 \\
50 \cdot 4 \\
18 \cdot 7 \\
10 \cdot 4 \\
26 \cdot 6 \\
50 \cdot 8 \\
9 \cdot 2 \\
33 \cdot 3 \\
45 \cdot 7 \\
98 \\
8 \cdot 0 \\
295 \\
107 \\
303 \\
8 \cdot 1 \\
87 \cdot 3 \\
49 \cdot 3 \\
21 \cdot 5 \\
39 \\
72 \\
28 \cdot 1 \\
65 \cdot 5 \\
26 \cdot 7 \\
9 \cdot 9 \\
6 \cdot 4 \\
133 \\
86 \\
150 \\
20 \\
14 \cdot 1 \\
9 \cdot 2 \\
32 \cdot 1 \\
51 \cdot 3 \\
101 \\
136 \\
19 \cdot 5 \\
153 \\
35 \\
13 \cdot 9 \\
50 \\
40 \cdot 1 \\
147 \\
64 \cdot 6 \\
-6 \\
\end{array}$ \\
\hline
\end{tabular}

A.M.L. = Acute myelogenous leukaemia.

A.L.L. = Acute lymphoblastic leukaemia.

of the patients were severely anaemic (haemoglobin concentrations less than $8 \mathrm{~g} / 100 \mathrm{ml}$.) and two patients had haemoglobins of less than $4 \mathrm{~g} / 100 \mathrm{ml}$. The platelet count was severely reduced in $34 \%$ of patients (less than $40,000 / \mu l$ ). The initial blast count of the patients showed that the number of patients with really high counts-those most useful to our immunotherapy programme because we immunize with allogenic cells (Powles et al., 1973 a)-was disappointingly few; only $10 \%$ had counts greater than $150,000 \mu \mathrm{l}$. The mean length of time patients were connected to the separator was two hours 55 minutes, but nine patients (with low counts) tolerated the procedure without undue discomfort for more than five hours.

\section{YIELD OF LEUKAEMIA CELLS}

The yield of leukaemia cells from the 73 donors ranged from $1.8 \times 10^{9}$ to $7.2 \times 10^{11}$ per hour (see table) and with red cell/white cell exchange, total yields of over $1 \times 10^{12}$ were obtained from single donors. As might be expected the yield was proportional to the initial blood white cell count (fig. 4), but there was considerable variability for individual cases. There was no difference between males and females and the yields for the two varieties of leukaemia were similar. Generally, the number of red cells collected with the leucocyte suspension increased with poorer yields (fig. 5), but this reflected the thin buffy layer in the centrifuge bowl in these patients, which necessitated also taking red cells. When patients had low numbers of leukaemia cells in the blood initially, however, then the more red cells that were collected with the buffy coat the higher the yield of leukaemia cells, presumably because there were blast cells trapped in the upper layers of the red cell fraction.

In low-count patients the blood-flow rate through the machine was important and poor yields were obtained in donors who had poor veins and bled slowly. In high-count patients this was less important because even low blood-flow 


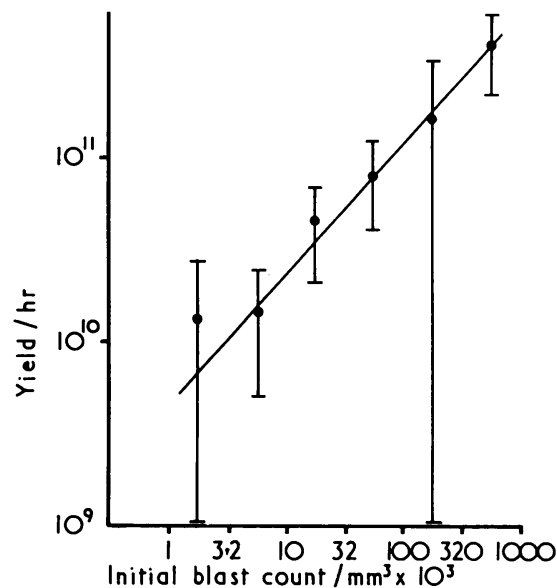
FIG. 4-Relationship between number of circulating
blasts of 73 patients leucopheresed and the yield/hr of blasts of 73 pati
these blasts.

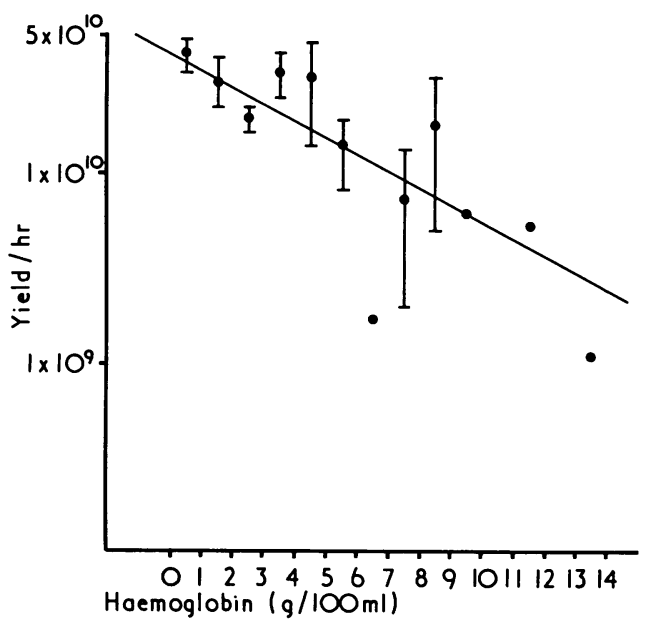

FIG. 5-Relationship between yield/hr and haemoglobin concentration in buffy coat collected from 73 patients.

rates gave buffy coats so thick that leucocytes could scarcely be withdrawn fast enough to stop the buffy layer accumulating in the bowl.

\section{INFLUENCE OF EXTENT OF DISEASE ON YIELD}

Twelve out of the 73 leucophereses did not reduce the number of leukaemia cells in the peripheral blood, even after large numbers of cells had been removed (table I). Seven of these 12 patients had acute lymphoblastic leukaemia. Failure to reduce the cell count was not more common in patients with extensive disease involving the liver, spleen, and lymph glands and seemed to be unrelated to the sedimentation rate or the extent of bone marrow infiltration. We did find, however, that it was easier to collect blast cells when the haemoglobin concentration of the blood passing through the machine was low, presumably because less were trapped in the red cell layer.

\section{ADVERSE EFFECTS OF LEUCOPHERESIS}

Twenty-two of the 73 patients $(30 \%)$ developed systemic disturbance during the leucopheresis. The most common occurrence (in 16 patients) was spontaneous occlusion of the vein donating the blood one to two hours after bleeding had begun. There was pallor and cooling of the extremities but at this time the patient was symptom free. If the machine continued to run then the patient developed a tachycardia, followed by a rigor without pyrexia (in 13 patients), and in one instance syncope. Generally, if the machine was stopped for a short period the patient fully recovered and the leucopheresis could continue without further problems. We learnt to recognize the significance of an occluded vein as an early warning sign and prevented the more serious disturbances by temporarily stopping the machine at that stage. The cause remains a mystery but because the symptoms can be averted and the leucopheresis later resumed it is unlikely that bacteria, pyogens, or excessive cooling of the extracorporeal blood are responsible. Other side effects were rare: three patients developed positional syncope after the procedure, three developed mild reactions to the transfused blood, one increased his pre-existing pyrexia, and one developed a transient severe unilateral headache. No patients developed spontaneous bleeding, and the platelet count of the donors after leucopheresis rarely dropped more than $10 \%$ below the initial count. In 11 cases the platelet count was higher than the initial count on completion of the leucopheresis.

\section{EFFECT OF LEUCOPHERESIS ON REMISSION RATE}

Of the 48 patients with acute myelogenous leukaemia who were subsequently treated with daunorubicin and cytosine arabinoside (Crowther et al., 1970), 46\% achieved complete remission compared with an overall remission rate of $43 \%$ for all myeloblastic leukaemia patients admitted to St. Bartholomews's Hospital between October 1969 and 1 February 1973 and treated with these same drugs. The remission rate for the 22 adult patients with acute lymphoblastic leukaemia who were given vincristine and prednisolone was $68 \%$.

\section{Discussion}

The purpose of collecting the leukaemia cells was for use as immunotherapy for patients with acute myelogenous leukaemia, and we have previously shown that if sufficient cells were given to these patients their remission length and survival time was doubled (Powles, 1973; Powles et al., 1973 a). Initially we used only autologous cells for immunotherapy (Powles et al., 1971 a) but it quickly became apparent that this severely limited the extent of the trial because only $25 \%$ of the patients provided enough cells for prolonged immunotherapy. When allogeneic cells were used one highcount patient could provide more than $1 \times 10^{12}$ cells, which was equivalent to 1,000 immunizing doses, and so leucopheresis of a few high-count patients was sufficient to enable a trial to be organized. These high-count patients gained direct benefit after leucopheresis, and if they passed into remission they were then immunized with cells from other donors.

At first sight it seemed a pity we could not predict which of the low-count patients would give good yields of cells on the separator. The reason why some patients during leucopheresis mobilize leukaemia cells into the circulation remains a mystery but it clearly is not related to the extent of extravascular disease. This problem is not now so important, however, because we collect leukaemia cells from all fit patients with circulating blast cells so that we may later measure in vitro host response to their disease after treatment. This is essential for developing better methods of immunotherapy.

There are two possible theoretical hazards to the donorbleeding after anticoagulation and undue delay before specific chemotherapy is given. In spite of being given heparin, 
there was not a single bleeding episode in the 73 patients studied, and this may reflect the popular concept at the moment of varying degrees of disseminated intravascular coagulation in these patients (Sultan et al., 1973). This could also explain why 11 patients, not transfused, had higher platelet counts on completion of separation than before the procedure in spite of the inevitable small loss of platelets into the buffy layer. The other problem was a possible reduction in the remission rate of patients leucopheresed because of the necessary delay in getting them to our unit and setting up the separator (in practice this often caused a delay of up to 24 hours), a factor known to influence the treatment of myelogenous leukaemia (Crowther et al., 1970). It was reassuring to find that the remission rate in this disease was not altered. The $68 \%$ remission rate for the adult high-count lymphoblastic patients was the same as reported in other series (Medical Research Council, 1971).

Recently a Blood Cell Seperator (Haemonetics 5830 Model 30 Blood Processor, Natick, Mass., U.S.A.) has been designed which uses an intermittent bleeding cycle for centrifugation of the blood. This machine is much cheaper than the continuous flow blood cell seperators but has the disadvantages of altering the donor's blood volume and removing platelets. These problems can to some extent be overcome and we are at present evaluating this instrument for use with leukaemia patients.

The current results of immunotherapy in acute myelogenous leukaemia make it reasonable to suppose that immunological treatment of acute leukaemia may play a definite role in the future management of these patients, and by necessity this will involve patients distributed throughout the country (already the Medical Research Council Leukaemia Working Party have a pilot study involving four centres).

For this to become a practical reality, however, large stores of cells must be collected for subsequent distribution, and because acute myelogenous leukaemia is not common it is economically sensible that this only be done in a limited number of specialized centres that have the necessary equipment. Though this requires that new patients should, if at all possible, be sent to these centres before they start treatment it does not mean that they need remain under the care of these centres. Subsequently the stored cells can be sent back to the referring hospital so that immunotherapy can be given close to where the patient lives. Clearly, when leucopheresing patients it is critical to avoid undue delay in specific chemotherapy, so careful co-operation and organization are required.

We are indebted for the support for this study to the Leukaemia Research Fund, the Imperial Cancer Research Fund, the Joseph Frazer Strong Trust, and the Medical Research Council. We thank the nursing staff of the cell separator units at the Royal Marsden Hospital, Surrey, and St. Bartholomew's Hospital, London, for their care of the patients.

\section{References}

Bloom, H. I G., et al. (1973). British fournal of Cancer, 27, 253.

Buckner, D., et al. (1969). Blood, 33, 353.

Children's Cancer Study Group A, U.S.A. (1973). Vaccination for the Maintenance of Remission in Childhood Leukaemia. Personal communication.

Crowther, D., et al. (1970). British Medical fournal, 4, 513.

Currie, G. A. (1972). British Fournal of Cancer, 26, 141 .

Freireich, E. J., Judson, G., and Levin, R. H. (1965). Cancer Research, 25, 1516.

Graw, R. G., et al. (1969). Lancet, 2, 77.

Haddow, A., and Alexander, P. (1964). Lancet, 1, 452.

Halpern, N. N., et al. (1965). Comptes Rendues Societe de Biologique, 153, 919.

Mathe, G. (1969). British Medical Fournal, 4, 7.

Mathe, G. (1969). British Medical fournal, 4, 7. (1969). British fournal of Cancer, 23, 814.

Mathe, G., Amiel, J-L., and Schwarzenberg, L. (1971). In Bone Marrow Transplantation and Leucocyte Transfusions. Springfield, Illinois, Charles C. Thomas.

Medical Research Council (1971). British Medical fournal, 4, 189.

Parr, I. (1972). British fournal of Cancer, 26, 174.

Powles, R. L., et al. (1971 a). British Medical fournal, 1, 486.

Powles, R. L., et al. (1971 b). British Medical fournal, 3, 664.

Powles, R. L. (1973). British fournal of Cancer, 28, Supp. 1, p. 262

Powles, R. L., et al. (1973 a). British fournal of Cancer, 28, 365.

Powles, R. L., et al. (1973 b). Cryobiology, 10, 282.

Sultan, C., Heilmann-Gouault, M., and Tulliez, M. (1973). British fournal of Haematology, 24, 255.

\title{
“Locked-in" Syndrome: Report of Seven Cases
}

\author{
C. H. HAWKES
}

British Medical fournal, 1974, 4, 379-382

\section{Summary}

Seven cases of the "locked-in" syndrome are described. This is a disorder in which a conscious, mute patient is completely paralysed apart from some form of eye movement, usually as a result of an infarct in the ventral pons. Such patients are often assumed to be in coma and as a result may be distressed by inappropriate conversation around the bedside.

\footnotetext{
Wessex Neurological Centre, Southampton University Hospitals, Southampton SO9 4XY

C. H. HAWKES, M.D., M.R.C.P., Senior Neurological Registrar
}

\section{Introduction}

For over 30 years neurologists have been acquainted with akinetic mutism. This is a somewhat ill-defined syndrome in which the patient is unable to perform any action apart from eye movement, but appears awake though he is probably not conscious (Plum and Posner, 1966). The disorder has been associated with lesions in the basal ganglia, cingulate gyrus, and brain stem. There is another condition similar to akinetic mutism but having important differences which is known variously as the "locked-in" syndrome, pseudocoma, deefferented state, and cerebromedullospinal disconnexion. Patients with this condition are completely paralysed except for some eyeball or eyelid movement but retain consciousness and may communicate with the examiner by eye signalling. Unless the observer is familiar with the disorder there is a high probability that it will be missed and the patient pronounced unconscious.

Over the past five years seven cases of the locked-in syndrome have been seen at the Wessex Neurological Centre, which suggests that it may be more common than has been realized. 